\title{
A Airman
}

Jurnal Teknik dan Keselamatan Transportasi

\section{Pemilihan Lokasi Bandar Udara Kabupaten Kolaka Utara Berbasis Analytical Hierarchy Process (AHP)}

\author{
Selection of Airport Location for North Kolaka Regency \\ Based Analytical Hierarchy Process (AHP)
}

\author{
Dewa Muhammad Fatwa Japari ${ }^{1}$, Muhammad Yamin Jinca ${ }^{2}$, Muhammad Fathien Azmy ${ }^{3}$ \\ dewwa.muhfatwa19@gmail.com,.my jinca@yahoo.com,fathienazmy@gmail.com
}

Universitas Hasanuddin

\begin{abstract}
ABSTRAK
Ketersediaan prasarana dan sarana transportasi merupakan suatu persyaratan utama dalam mendukung pengembangan wilayah suatu daerah, terutama bagi daerah-daerah yang mempunyai potensi sumberdaya yang besar, namun kurang didukung oleh prasarana dan sarana transportasi yang memadai. Dalam rencana tata ruang wilayah (RTRW) Kabupaten Kolaka Utara menjelaskan bahwa terdapat tiga alternatif lokasi pembangunan bandar udara. Menggunakan metode proyeksi dan deskripsi kualitatif untuk mengetahui proyeksi jumlah penduduk, proyeksi prakiraan jumlah penumpang angkutan udara, dan sistem transportasi regional dari dan menuju Kolaka Utara dan sekitarnya, menggunakan metode Analytical Hierarchy Process (AHP) untuk menentukan alternatif lokasi pembangunan bandar udara baru. Berdasarkan hasil analisis, lokasi yang paling strategis untuk pembangunan bandar udara yaitu Kecamatan Kodeohadengan nilai bobot sebesar 0,47. Nilai bobot menunjukkan bahwa alternatif lokasi terbaik dari ketiga alternatif lokasi yang didukung oleh sembilan aspek terutama dari aspek ekonomi, topografi, dan kondisi permukaan tanah. Hal ini disebabkan karena berada di tengah-tengah Kabupaten Kolaka Utara dan memiliki lahan yang berpotensi untuk dibangun sebuah bandara yakni area tambak dan persawahan yang sudah tidak produktif.
\end{abstract}

Kata kunci: lokasi; bandar udara; AHP; Kabupaten Kolaka Utara; tata ruang

\section{ABSTRACT}

The availability of transportation infrastructure and facilities is a major requirementin supporting the development of a region, especially for regions that have large potential resources, but are not supportedby adequate infrastructure and transportations. In the regional spatial plan (RTRW) North Kolaka Regency explained that there are three alternative airport construction sites. Using the projection method andqualitative description to find out population projections, projectionsof estimated number of air transport passengers, and regional transportation systems fromand towards North Kolaka and its surroundings, using the Analytical Hierarchy Process (AHP) method to determine alternative locations for the deveolopment of new airport. Based on the results of the analysis, the most strategic location forairport development which is Kodeoha District with a weight value of 0.47. Weight values indicate that the best alternative location of the three alternativesthe location is supported by nine aspects mainly from economic, topographic, and surface conditions. This is due to being in the middle North Kolaka Regency and has land with the potential to develop an airport that is an area of ponds and rice fields that are no longer productive.

Keywords: location; airport; AHP; North Kolaka Regency; spatial 


\section{PENDAHULUAN}

Kolaka Utara adalah satu dari 17 kabupaten/kota di Provinsi Sulawesi Tenggara yang terletak di ujung utara [1]. Melalui Kabupaten ini dapat diakses Provinsi Sulawesi Selatan melalui jalur darat maupun jalur penyeberangan laut. Kabupaten Kolaka Utara berbatasan dengan Kabupaten Luwu Timur (Provinsi Sulawesi Selatan). Ketersediaan prasarana dan sarana transportasi merupakan syarat utama dalam mendukung pengembangan wilayah suatu daerah, terutama bagi daerah-daerah yang mempunyai potensi sumberdaya yang besar, namun kurang didukung prasarana dan sarana transportasi yang memadai. Alternatif lokasi perencanaan bandar udara baru di Kabupaten Kolaka Utara berada pada Kecamatan Katoi, Kodeoha, dan Tiwu [2].

Cakupan pelayanan bandar udara terbagi menjadi: untuk Pulau Jawa dan Sumatera, cakupan wilayah pelayanan bandara adalah $100 \mathrm{~km}$ atau jarak dua bandar udara $200 \mathrm{~km}$. Untuk Pulau Kalimantan dan Sulawesi, cakupan wilayah pelayanan bandara adalah $60 \mathrm{~km}$ atau jarak dua bandar udara $120 \mathrm{~km}$. Untuk Bali, Nusa Tenggara, Kepulauan Maluku dan Pulau Papua, cakupan wilayah pelayanan bandara adalah $30 \mathrm{~km}$ atau jarak dua bandar udara $60 \mathrm{~km} \mathrm{[3].}$

Berdasarkan uraian diatas, cakupan pelayanan bandar udara di Pulau Sulawesi khususnya Provinsi Sulawesi Tenggara bahwa Kolaka Utara masih belum tercakup oleh pelayanan bandar udara berdasarkan bandar udara eksisting.

Transportasi adalah pemindahan manusia atau barang dengan menggunakan wahana yang digerakkan oleh manusia atau mesin [4]. Transportasi berperan mendorong pemerataan pembangunan, melayani kebutuhan masyarakat luas baik di perkotaan maupun perdesaan dengan harga terjangkau, mendukung peningkatan kesejahteraan masyarakat di wilayah pedalaman dan terpencil, serta untuk melancarkan distribusi barang dan jasa dan mendorong pertumbuhan sektor-sektor ekonomi nasional [5].

Angkutan udara sebagai salah satu moda transportasi yang ditata dalam sistem transportasi nasional telah menjadi salah satu penghubung wilayah nasional dan internasional dalam rangka mendorong dan mempercepat pembangunan nasional dan peningkatan kesejahteraan rakyat. Angkutan udara mempunyai peran yang cukup besar dalam menun- jang kegiatan ekonomi suatu daerah terutama sektor perdagangan dan pariwisata.

Bandar udara adalah kawasan di daratan dan atau perairan dengan batas-batas tertentu yang digunakan sebagai tempat pesawat udara mendarat dan lepas landas, naik turun penumpang, bongkar muat barang, dan tempat perpindahan intra dan antarmoda transportasi yang dilengkapi dengan fasilitas keselamatan dan keamanan penerbangan serta fasilitas pokok dan fasilitas penunjang lainnya [6].

Berdasarkan permasalahan yang terjadi maka di rumuskan pertanyaan penelitian sebagai berikut: (1) Bagaimana sistem transportasi regional dari dan menuju Kolaka Utara dan sekitarnya, dan (2) Bagaimanakah penentuan lokasi bandara menggunakan metode AHP di Kabupaten Kolaka Utara?

\section{METODE}

Dalam penelitian menggunakan metode proyeksi, deskriptif kualitatif dan Analytical Hierarchy Process (AHP). Penelitian ini dilaksanakan di Kecamatan Katoi, Kodeoha, dan Tiwu Kabupaten Kolaka Utara.Pengumpulan datasekunder dan primer dilakukan melalui studi literatur, survei lapangan dan wawancara yang dilakukan secara mendalam (Atmia, 2018). Variabel yang digunakan dalam penelitian ini adalah, jarak tempuh, waktu tempuh, biaya transportasi, prakiraan jumlah penumpang, dan penilaian sistem pendukung keputusan.

$$
\mathrm{P}_{\mathrm{t}+\mathrm{n}}=\mathrm{P}_{\mathrm{t}}(1+\mathrm{i})^{\mathrm{n}}(1)
$$

Keterangan

$\mathrm{P}_{\mathrm{t}+\mathrm{n}} \quad=$ jumlah yang dicari pada tahun $\mathrm{ke}(\mathrm{t}+\mathrm{n})$

$\mathrm{P}_{\mathrm{t}} \quad=$ jumlah pada tahun ke $\mathrm{t}$

$\mathrm{i}=$ tingkat pertumbuhan

$\mathrm{n} \quad=$ selisih tahun 
$\mathrm{Y}=\mathrm{a}+\mathrm{bX}(2)$

$\mathrm{Y} \quad=$ jumlah penumpang

a $\quad=$ konstanta

$\mathrm{b} \quad=$ koefisien regresi

$\mathrm{X} \quad=$ jumlah penduduk

a $\quad=\frac{\left(\sum \mathrm{Y}\right)\left(\sum \mathrm{X}^{2}\right)-\left(\sum \mathrm{X}\right)\left(\sum \mathrm{XY}\right)}{\mathrm{n}\left(\sum \mathrm{X}^{2}\right)-\left(\sum \mathrm{X}\right)^{2}}(3)$

$\mathrm{b} \quad=\frac{\mathrm{n}\left(\sum \mathrm{XY}\right)-\left(\sum \mathrm{X}\right)\left(\sum \mathrm{Y}\right)}{\mathrm{n}\left(\sum \mathrm{X}^{2}\right)-\left(\sum \mathrm{X}\right)^{2}}(4)$

Tabel 1. Skala Penilaian dalam Sistem Pendukung Keputusan

\begin{tabular}{|c|c|c|}
\hline $\begin{array}{c}\text { Intensitas } \\
\text { kepentingan }\end{array}$ & Keterangan & Penjelasan \\
\hline 1 & $\begin{array}{c}\text { Kedua elemen sama } \\
\text { pentingnya }\end{array}$ & $\begin{array}{c}\text { Dua elemen mempunyai } \\
\text { pengaruhyang sama besar }\end{array}$ \\
\hline 3 & $\begin{array}{c}\text { Elemen satu yang sedikit } \\
\text { lebih penting daripada } \\
\text { elemen yang lainnya }\end{array}$ & $\begin{array}{c}\text { Pengalaman dan penilaian } \\
\text { sedikit menyokong satu } \\
\text { elemen yang lainnya }\end{array}$ \\
\hline 5 & $\begin{array}{c}\text { Elemen yang satu lebih } \\
\text { penting daripada elemen } \\
\text { yang lainnya }\end{array}$ & $\begin{array}{c}\text { Pengalaman dan penilaian } \\
\text { sangat kuat menyokong satu } \\
\text { elemen yang lainnya }\end{array}$ \\
\hline 7 & $\begin{array}{c}\text { Satu elemen jelas lebih } \\
\text { mutlak penting daripada } \\
\text { elemen yang lainnya }\end{array}$ & $\begin{array}{c}\text { Satu elemen yang kuat } \\
\text { disokong dan dominan terlihat } \\
\text { dalam praktek }\end{array}$ \\
\hline $\begin{array}{c}\text { Satu elemen mutlak } \\
\text { penting daripada elemen } \\
\text { yang lainnya }\end{array}$ & $\begin{array}{c}\text { Bukti yang mendukung } \\
\text { elemen yang satu terhadap } \\
\text { elemen lain memiliki tingkat } \\
\text { penegasan tertinggi yang } \\
\text { mungkin menguatkan }\end{array}$ \\
\hline $2,4,6,8$ & $\begin{array}{c}\text { Nilai-nilai antara 2 nilai } \\
\text { pertimbangan yang } \\
\text { berdekatan }\end{array}$ & $\begin{array}{c}\text { Nilai ini diberikan bila ada } \\
\text { kompromi diantara dua } \\
\text { pilihan }\end{array}$ \\
\hline
\end{tabular}

\section{HASIL DAN PEMBAHASAN}

\section{Topografi dan kemiringan lereng}

Kondisi topografi lokasi alternatif rencana pembangunan bandar udara terdiri dari wilayah dataran rendah dan wilayah perbukitan. Daerah lokasi perencanaan banda udara di ketinggian 5 8 mdpl [8].

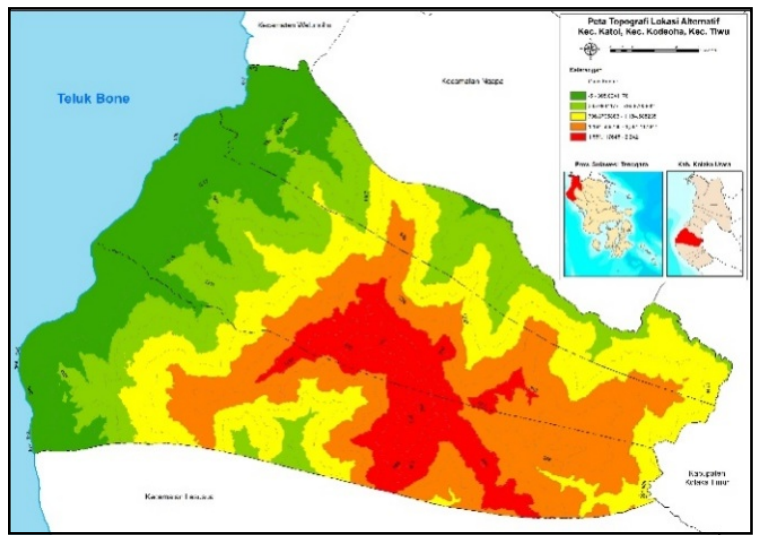

Gambar 1. Peta topografi Lokasi Alternatif Sumber: [2], dimodifikasi oleh penulis tahun 2019
Kemiringan lereng di lokasi alternatif rencana pembangunan bandara yaitu $0^{\circ}-2^{\circ}, 2^{\circ}-15^{\circ}$, dan $15^{\circ}-40^{\circ}$. [8]

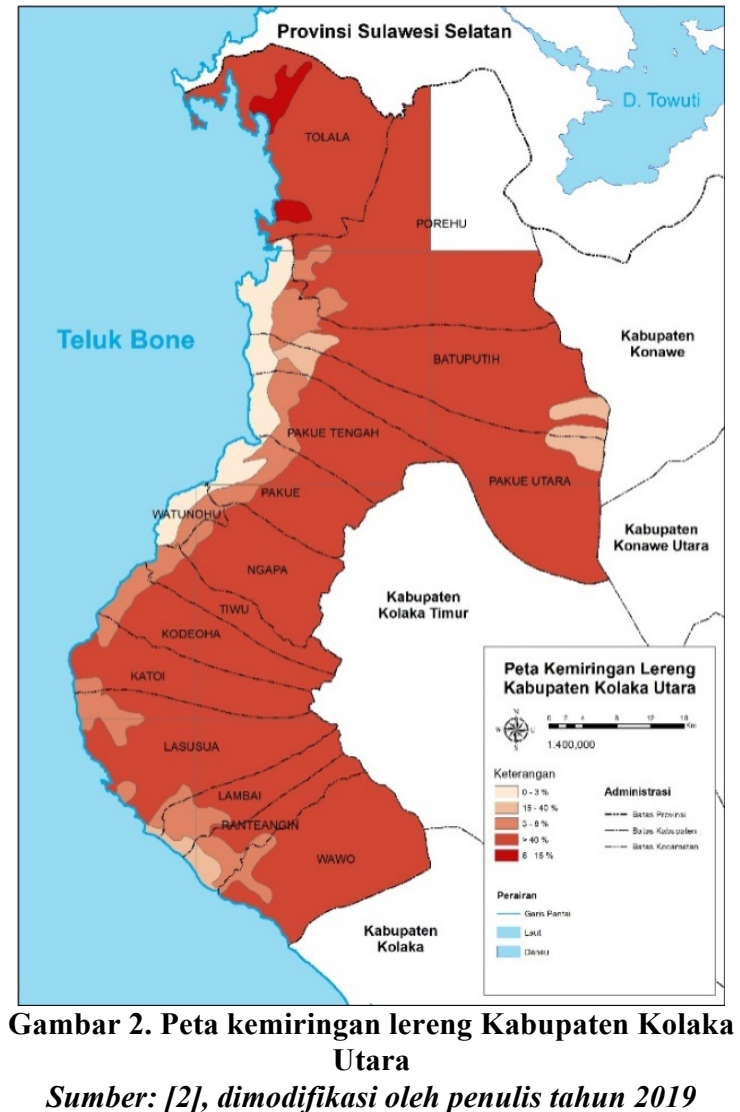

\section{Geologi}

Satuan Geomorfologi Lipat - Patahan yang meliputi hampir $80 \%$ dari seluruh wilayah Kabupaten Kolaka Utara.Satuan Morfologi Perbukitan Karst yang tersebar di sebelah selatan (dominan), di sebelah barat memanjang ke arah utara serta secara spot-spot di bagian tengah Kabupaten Kolaka Utara mencakup sekitar $15 \%$. Satuan dataran pantai dan alluvial sekitar $5 \%$ yang memanjang mengikuti pantai Teluk Bone dan lembah sungai yang ada [9].

Patahan Geologi yang dominan di Kabupaten Kolaka Utara dipengaruhi oleh Sesar Palu Koro yang merupakan kelanjutan Sesar Sorong yang melibatkan Kerak Samudera Pasifik.Adapun beberapa satuan batuan dari tua ke muda yaitu (1) Batuan Metamorf (Malihan), (2) Marmer (Batu Pualam), (3) Batuan Terobosan, (4) 
Batuan Formasi Meluhu, (5) Batuan Ofiolit yang terdiri dari kelompok batuan peridotit, (6) Batuan Formasi Pandua, (7) Batuan Formasi Matano, dan (8) Batuan Formasi Tokala.

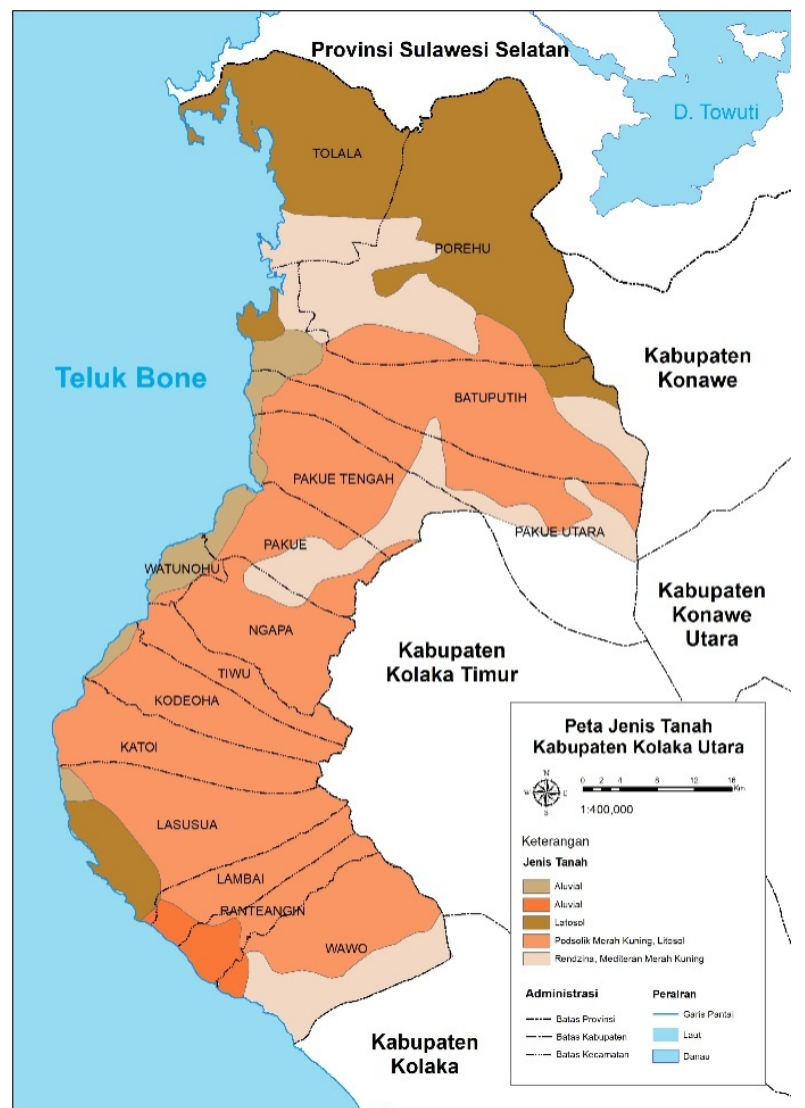

Gambar 3. Peta jenis tanah Kabupaten Kolaka Utara Sumber:[2], dimodifikasi oleh penulis tahun 2019

\section{Akses Moda Transportasi}

Mengakses Kabupaten Kolaka Utara dapat melalui jalur darat maupun jalur laut dalam hal ini adalah multimoda. Mengakses Kolaka Utara dari Kota Makassar melalui jalur darat dapat di tempuh dalam 19 jam dan biaya Rp. 380.000,00 dengan rute perjalanan Kota Makassar-Kab. Maros - Kab. Pangkep - Kab. Barru - Kota Pare-pare - Kab. Sidrap - Kab. Wajo - Kab. Luwu - Kota Palopo Kab. Luwu Utara - Kab. Luwu Timur - Kab. Kolaka Utara.Sedangkan melalui jalur laut dapat di temput dalam 11 jam dan biaya Rp. 250.000,00 dengan rute perjalanan Kota Makassar - Kab. Maros - Kab. Pangkep - Kab. Barru - Kota Parepare - Kab. Sidrap - Pelabuhan Siwa - Pelabuhan Tobaku.

\section{Jarak Bandar Udara Sekitar}

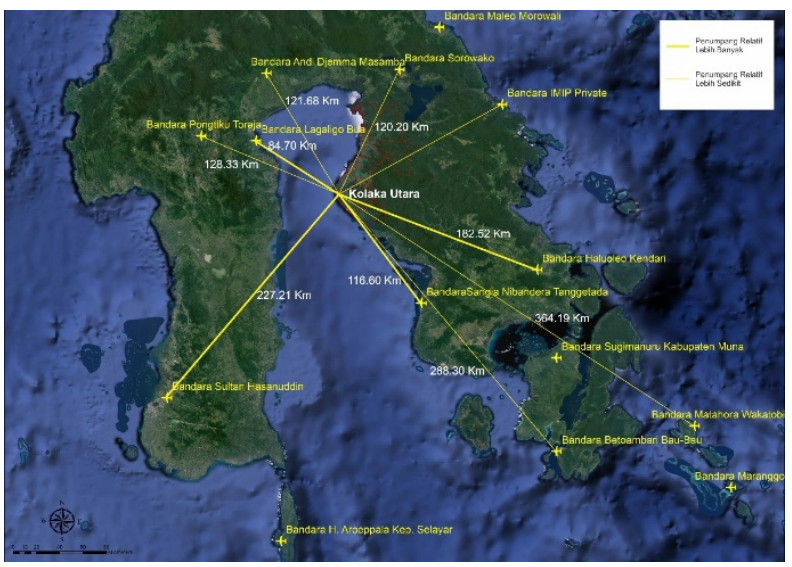

Gambar 4. Bandar Udara di Sekitar Kolaka Utara Sumber: [5], dimodifikasi oleh penulis tahun 2019

Tabel 2. Moda Transportasi, Jarak, Waktu, dan Biaya Transportasi Menuju Kolaka Utara dan Sekitarnya

\begin{tabular}{|c|c|c|c|c|c|c|c|}
\hline \multirow{2}{*}{ No } & \multirow{2}{*}{$\begin{array}{l}\text { Daerah } \\
\text { Tujuan }\end{array}$} & \multirow{2}{*}{$\begin{array}{c}\text { Moda } \\
\text { Transportasi }\end{array}$} & \multirow{2}{*}{ Jarak } & \multirow{2}{*}{ Waktu Tempuh } & \multirow{2}{*}{ Biaya } & \multicolumn{2}{|c|}{ Moda Transportasi Udara } \\
\hline & & & & & & Biaya & Waktu \\
\hline 1 & Kota Kendari & Darat & $309 \mathrm{~km}$ & $8 \mathrm{jam}$ & Rp 130.000 & Rp 650.900 & 50 menit \\
\hline 2 & Kolaka & Darat & $145,1 \mathrm{~km}$ & $3,5 \mathrm{jam}$ & $\operatorname{Rp} 70.000$ & $\operatorname{Rp} 332.200$ & 30 menit \\
\hline \multirow{2}{*}{3} & \multirow{2}{*}{ Kota Palopo } & Darat & $322,8 \mathrm{~km}$ & $10 \mathrm{jam}$ & Rp 180.000 & \multirow{2}{*}{ Rp 332.200} & \multirow{2}{*}{30 menit } \\
\hline & & Multimoda & $162,6 \mathrm{~km}$ & $6 \mathrm{jam}$ & Rp 150.000 & & \\
\hline 4 & Sorowako & Darat & $181 \mathrm{~km}$ & $6 \mathrm{jam}$ & Rp 100.000 & Rp 481.500 & 45 menit \\
\hline \multirow{2}{*}{5} & \multirow{2}{*}{ Enrekang } & Darat & $445,1 \mathrm{~km}$ & 14 jam & $\operatorname{Rp} 250.000$ & \multirow{2}{*}{ Rp 481.500} & \multirow{2}{*}{45 menit } \\
\hline & & Multimoda & $213,2 \mathrm{~km}$ & $11 \mathrm{jam}$ & $\operatorname{Rp} 200.000$ & & \\
\hline \multirow{2}{*}{6} & \multirow{2}{*}{ Toraja } & Darat & $418,8 \mathrm{~km}$ & $12 \mathrm{jam}$ & $\operatorname{Rp} 200.000$ & \multirow{2}{*}{$\operatorname{Rp} 481.500$} & \multirow{2}{*}{45 menit } \\
\hline & & Multimoda & $258,1 \mathrm{~km}$ & 9 jam & $\operatorname{Rp} 150.000$ & & \\
\hline \multirow{2}{*}{7} & \multirow{2}{*}{$\begin{array}{c}\text { Kota } \\
\text { Makassar }\end{array}$} & Darat & $701,1 \mathrm{~km}$ & $19 \mathrm{jam}$ & $\operatorname{Rp} 380.000$ & \multirow{2}{*}{$\operatorname{Rp} 468.600$} & \multirow{2}{*}{50 menit } \\
\hline & & Multimoda & $337,4 \mathrm{~km}$ & $11 \mathrm{jam}$ & $\operatorname{Rp} 250.000$ & & \\
\hline \multirow{2}{*}{8} & \multirow{2}{*}{ Pare-Pare } & Darat & $548 \mathrm{~km}$ & $15 \mathrm{jam}$ & $\operatorname{Rp} 280.000$ & \multirow{2}{*}{ Rp 452.200} & \multirow{2}{*}{$4 \mathrm{jam}$} \\
\hline & & Multimoda & $180,9 \mathrm{~km}$ & $5,5 \mathrm{jam}$ & Rp 100.000 & & \\
\hline 9 & Bau-Bau & Multimoda & $535,8 \mathrm{~km}$ & $20 \mathrm{jam}$ & $\operatorname{Rp} 322.000$ & Rp 440.400 & 50 menit \\
\hline
\end{tabular}


Tabel 3. Jarak Bandara Sekitar ke Kolaka Utara

\begin{tabular}{|c|c|c|c|}
\hline No & Bandar Udara & $\begin{array}{c}\text { Jarak } \\
(\mathbf{k m})\end{array}$ & $\begin{array}{c}\text { Kebijakan } \\
\text { Tatanan } \\
\text { Kebandarudaran }\end{array}$ \\
\hline 1 & Sorowako & 120,20 & \multirow{9}{*}{$\begin{array}{c}\text { Berdasarkan } \\
\text { Peraturan Menteri } \\
\text { Perhubungan } \\
\text { Nomor PM } 69 \\
\text { Tahun } 2013 \\
\text { Tentang Tatanan } \\
\text { Kebandarudaraan } \\
\text { bahwa cakupan } \\
\text { pelayanan bandar } \\
\text { udara untuk Pulau } \\
\text { Sulawesi dan } \\
\text { Kalimantan } \\
\text { adalah } 60 \mathrm{~km}\end{array}$} \\
\hline 2 & $\begin{array}{l}\text { Andi Djemma - } \\
\text { Masamba }\end{array}$ & 121,68 & \\
\hline 3 & $\begin{array}{l}\text { Sangia Nibandera - } \\
\text { Pomalaa }\end{array}$ & 116,60 & \\
\hline 4 & Lagaligo - Bua & 84,70 & \\
\hline 5 & Haluoleo - Kendari & 182,52 & \\
\hline 6 & Pongtiku - Toraja & 128,33 & \\
\hline 7 & $\begin{array}{l}\text { Sultan Hasanuddin - } \\
\text { Makassar }\end{array}$ & 227,21 & \\
\hline 8 & $\begin{array}{l}\text { Betoambari-Bau- } \\
\text { bau }\end{array}$ & 288,30 & \\
\hline 9 & $\begin{array}{l}\text { Matahora - } \\
\text { Wakatobi }\end{array}$ & 364,19 & \\
\hline
\end{tabular}

Disekitar Kabupaten Kolaka Utara terdapat beberapa bandar udara, baik bandar udara yang di kelola oleh pemerintah (PT. Angkasa Pura I), yang dikelola oleh swasta maupun bandar udara baru. Bandar udara tersebut yaitu Bandar Udara Sorowako, Bandar Udara Andi Djemma Masamba, Bandar Udara Sangia Nibandera Pomalaa, Bandar Udara Lagaligo - Bua, Bandar Udara Haluoleo - Kendari, Bandar Udara Pongtiku - Toraja, Bandar Udara Sultan Hasanuddin Makassar, Bandar Udara Betoambari - Bau-Bau, dan Bandar Udara Matahora - Wakatobi. Bandarabandara tersebut tersebar di Provinsi Sulawesi Selatan dan Sulawesi Tenggara.

\section{Proyeksi Penduduk dan Penumpang}

Pertumbuhan penduduk suatu wilayah dipengaruhi oleh beberapa faktor, seperti angka kelahiran lebih besar dibandingkan angka kematian, begitu pula faktor migrasi masuk lebih besar daripada migrasi keluar. Kedua faktor tersebut merupakan faktor alamiah, sementara itu disisi lain meningkatnya derajat kesehatan, pendidikan dan ekonomi masyarakat tentunya menjadi faktor ikutan dari kedua faktor alamiah tersebut di atas.

Tabel 4. Jumlah Penduduk Kabupaten Kolaka Utara Tahun 2015 - 2019

\begin{tabular}{cccc}
\hline \multirow{2}{*}{ Tahun } & Jumlah & \multicolumn{2}{c}{$\begin{array}{c}\text { Pertumbuhan Prakiraan } \\
\text { Prakiraan }\end{array}$} \\
\cline { 3 - 4 } & Penumpang & Jiwa & Persen (\%) \\
\hline 2014 & 136883 & - & - \\
2015 & 140706 & 3823 & 2,72
\end{tabular}

\begin{tabular}{rccc}
2016 & 142614 & 1908 & 1,34 \\
2017 & 144681 & 2067 & 1,43 \\
2018 & 147863 & 3182 & 2,15 \\
\hline \multicolumn{1}{c}{ Rata-rata } & - & - & 1,91 \\
\hline Sumber: $[8]$ & \\
$\mathrm{P}_{2019}=147863(1+1,91 \%)^{(2019-2018)}$ & \\
$\mathrm{P}_{2019}=147863(1+0,0191)^{(1)}$ & \\
$\mathrm{P}_{2019}=147863(1,0191)$ & \\
$\mathrm{P}_{2019}=150687,18$ & \\
$\mathrm{P}_{2019}=150687$ jiwa
\end{tabular}

Tabel 5. Hasil Perhitungan Jumlah Penduduk Kabupaten Kolaka Utara Tahun 2019 - 2039

\begin{tabular}{cccc}
\hline Tahun & $\begin{array}{c}\text { Jumlah } \\
\text { Penduduk } \\
\text { (jiwa) }\end{array}$ & Tahun & $\begin{array}{c}\text { Jumlah } \\
\text { Penduduk } \\
\text { (jiwa) }\end{array}$ \\
\hline 2019 & 150687 & 2030 & 185550 \\
\hline 2020 & 153565 & 2031 & 189094 \\
\hline 2021 & 156498 & 2032 & 192706 \\
\hline 2022 & 159488 & 2033 & 196386 \\
\hline 2023 & 162534 & 2034 & 200137 \\
\hline 2024 & 165638 & 2035 & 203960 \\
\hline 2025 & 168802 & 2036 & 207856 \\
\hline 2026 & 172026 & 2037 & 211826 \\
\hline 2027 & 175312 & 2038 & 215872 \\
\hline 2028 & 178660 & 2039 & 219995 \\
\hline 2029 & 182072 & & \\
\hline
\end{tabular}

Prediksi jumlah penduduk dari tahun 2019 sampai tahun 2039 mengalami peningkatan dalam setiap tahunnya. Pada tahun 2025, prediksi jumlah penduduk yaitu 168.802 jiwa dan pada tahun 2030 prediksi jumlah penduduk yaitu 185.550 jiwa.

Tabel 6. Jumlah Prakiraan Penumpang Angkutan Udara Kabupaten Kolaka Utara Tahun 2015 - 2019

\begin{tabular}{cccc}
\hline \multirow{2}{*}{ Tahun } & $\begin{array}{c}\text { Jumlah } \\
\text { Prakiraan } \\
\end{array}$ & \multicolumn{2}{c}{$\begin{array}{c}\text { Pertumbuhan Prakiraan } \\
\text { Jumlah Penumpang }\end{array}$} \\
\cline { 3 - 4 } & Penumpang & Jiwa & Persen (\%) \\
\hline 2015 & 51736 & - & - \\
2016 & 55261 & 3525 & 6,38 \\
2017 & 59192 & 3931 & 6,64 \\
2018 & 63578 & 4386 & 6,90 \\
2019 & 68472 & 4894 & 7,15 \\
\hline Rata-rata & - & - & 6,77 \\
\hline
\end{tabular}
Sumber: [1]

$$
\begin{array}{ll}
\mathrm{Y} & =-166120+1,58 \mathrm{X} \\
\mathrm{Y}_{2020} & =-166120+1,58 \mathrm{X}_{2020} \\
\mathrm{Y}_{2020} & =-166120+1,58(153565) \\
\mathrm{Y}_{2020} & =76512 \text { jiwa }
\end{array}
$$


Tabel 7. Hasil Perhitungan Jumlah Penumpang Angkutan Udara Kabupaten Kabupaten Kolaka Utara Tahun 2020 - 2039

\begin{tabular}{cccc}
\hline Tahun & $\begin{array}{c}\text { Jumlah } \\
\text { Penduduk } \\
\text { (jiwa) }\end{array}$ & Tahun & $\begin{array}{c}\text { Jumlah } \\
\text { Penduduk } \\
\text { (jiwa) }\end{array}$ \\
\hline 2020 & 76512 & 2030 & 127049 \\
\hline 2021 & 81146 & 2031 & 132648 \\
\hline 2022 & 85871 & 2032 & 138355 \\
\hline 2023 & 90683 & 2033 & 144170 \\
\hline 2024 & 95588 & 2034 & 150096 \\
\hline 2025 & 100587 & 2035 & 156136 \\
\hline 2026 & 105681 & 2036 & 162292 \\
\hline 2027 & 110873 & 2037 & 168565 \\
\hline 2028 & 116162 & 2038 & 174957 \\
\hline 2029 & 121553 & 2039 & 181472 \\
\hline
\end{tabular}

\section{Matriks Aspek Penilaian}

Tabel 8. Matriks Penilaian dari 27 Responden

\begin{tabular}{|c|c|c|c|c|c|c|c|c|c|}
\hline Kriteria & A & B & C & D & E & F & G & H & I \\
\hline A & 1,00 & 1,92 & 0,78 & 0,32 & 0,93 & 2,38 & 1,83 & 0,74 & 3,28 \\
\hline B & 0,52 & 1,00 & 2,73 & 1,15 & 1,39 & 2,29 & 3,18 & 1,48 & 0,61 \\
\hline C & 1,29 & 0,37 & 1,00 & 2,48 & 2,36 & 2,24 & 1,87 & 2,30 & 2,04 \\
\hline D & 3,08 & 0,87 & 0,40 & 1,00 & 2,14 & 1,76 & 2,58 & 1,59 & 0,29 \\
\hline E & 1,08 & 0,73 & 0,42 & 0,47 & 1,00 & 1,94 & 2,20 & 1,40 & 2,22 \\
\hline F & 0,42 & 0,44 & 0,44 & 0,57 & 0,51 & 1,00 & 1,22 & 1,60 & 2,77 \\
\hline G & 0,55 & 0,31 & 0,53 & 0,39 & 0,45 & 0,82 & 1,00 & 2,39 & 0,43 \\
\hline H & 1,36 & 0,68 & 0,44 & 0,63 & 0,71 & 0,63 & 0,42 & 1,00 & 3,09 \\
\hline I & 0,30 & 1,65 & 0,49 & 3,44 & 0,45 & 0,36 & 2,33 & 0,32 & 1,00 \\
\hline Jumlah & $\mathbf{9 , 6 1}$ & $\mathbf{7 , 9 6}$ & $\mathbf{7 , 2 3}$ & $\mathbf{1 0 , 4 5}$ & $\mathbf{9 , 9 4}$ & $\mathbf{1 3 , 4 2}$ & $\mathbf{1 6 , 6 3}$ & $\mathbf{1 2 , 8 2}$ & $\mathbf{1 5 , 7 4}$ \\
\hline
\end{tabular}

Keterangan
A = Kesesuaian dengan RTRW
$\mathrm{B}=$ Ekonomi
$\mathrm{C}=$ Topografi
$\mathrm{D}=$ Kondisi permukaan tanah, kelandaian permukaan tanah
$\mathrm{E}$ = Daya dukung dan struktur tanah
$\mathrm{F} \quad=$ Peruntukan Lahan
$\mathrm{G} \quad=$ Relokasi penduduk
$\mathrm{H}=$ Infrastruktur dan jaringan utilitas
I = Usability factor, meliputi arah angina

Tabel 9. Hasil Perhitungan Matriks Aspek Penilaian

\begin{tabular}{cccccc}
\hline Iterasi & MEV & CI & RI & CR & Ket \\
\hline 3 & 10,22 & 0,15 & 1,45 & 0,10 & $\begin{array}{c}\text { CR } \leq 0,10 \\
\text { konsisten }\end{array}$ \\
\hline
\end{tabular}

Perhitungan AHP terhadap kriteria penentuan lokasi berdasarkan hasil penilaian responden bahwa nilai $\mathrm{CR}>0,1$ yangartinya tidak konsisten. Langkah selanjutnya adalah melakukan revisi pada matriks, berdasarkan hasil revisi padamatriks bahwa nilai CR masih kurang dari 0,1 . Langkah selanjutnya adalah masih dilakukan revisi padamatriks sehingga berdasarkan hasil perhitungan revisi pada matriks yang kedua ini memilikii nilai $\mathrm{CR}<10$ yang artinya sudah konsisten.

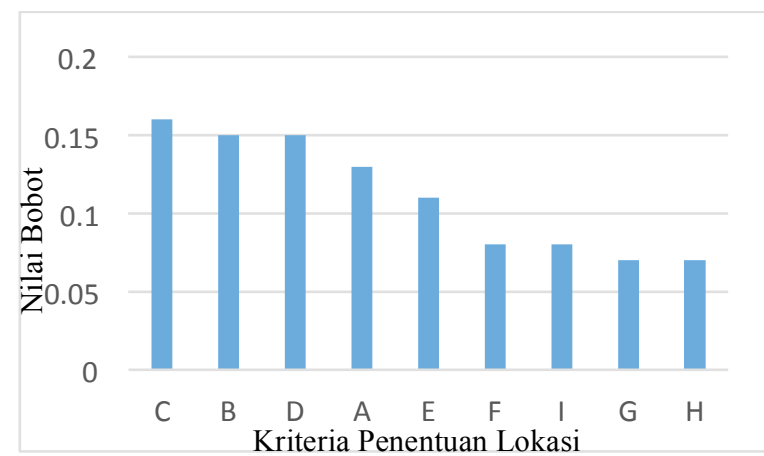

Gambar 5. Diagram Bobot Prioritas Terhadap Kriteria Penentuan Lokasi

\section{Aspek Kesesuaian Terhadap Lokasi}

Tabel 10. Matriks Penilaian dari 27 Responden Terhadap Lokasi

\begin{tabular}{cccc}
\hline & Kec. Katoi & Kec. Kodeoha & Kec. Tiwu \\
\hline A & $\mathbf{2 , 3 6}$ & $\mathbf{2 , 3 3}$ & $\mathbf{8 , 3 0}$ \\
\hline Kec. Katoi & 1,00 & 1,13 & 2,08 \\
\hline Kec. Kodeoha & 0,88 & 1,00 & 5,22 \\
\hline Kec. Tiwu & 0,48 & 0,19 & 1,00 \\
\hline B & $\mathbf{2 , 6 5}$ & $\mathbf{2 , 2 0}$ & $\mathbf{6 , 5 2}$ \\
\hline Kec. Katoi & 1,00 & 0,93 & 1,78 \\
\hline Kec. Kodeoha & 1,08 & 1,00 & 3,74 \\
\hline Kec. Tiwu & 0,56 & 0,27 & 1,00 \\
\hline C & $\mathbf{2 , 4 2}$ & $\mathbf{2 , 3 6}$ & $\mathbf{6 , 8 3}$ \\
\hline Kec. Katoi & 1,00 & 1,10 & 1,98 \\
\hline Kec. Kodeoha & 0,92 & 1,00 & 3,85 \\
\hline Kec. Tiwu & 0,51 & 0,26 & 1,00 \\
\hline D & $\mathbf{2 , 6 8}$ & $\mathbf{2 , 0 6}$ & $\mathbf{7 , 6 4}$ \\
\hline Kec. Katoi & 1,00 & 0,84 & 2,11 \\
\hline & Kec. Katoi & Kec. Kodeoha & Kec. Tiwu \\
\hline Kec. Kodeoha & 1,21 & 1,00 & 4,52 \\
\hline Kec. Tiwu & 0,48 & 0,22 & 1,00 \\
\hline E & $\mathbf{2 , 5 2}$ & $\mathbf{2 , 2 3}$ & $\mathbf{6 , 9 1}$ \\
\hline Kec. Katoi & 1,00 & 0,97 & 2,10 \\
\hline Kec. Kodeoha & 1,04 & 1,00 & 3,81 \\
\hline Kec. Tiwu & 0,48 & 0,26 & 1,00 \\
\hline F & $\mathbf{2 , 4 7}$ & $\mathbf{2 , 1 7}$ & $\mathbf{7 , 7 4}$ \\
\hline Kec. Katoi & 1,00 & 0,91 & 2,75 \\
\hline Kec. Kodeoha & 1,10 & 1,00 & 3,99 \\
\hline Kec. Tiwu & 0,37 & 0,25 & 1,00 \\
\hline G & $\mathbf{2 , 4 0}$ & $\mathbf{2 , 2 5}$ & $\mathbf{7 , 6 2}$ \\
\hline Kec. Katoi & 1,00 & 0,99 & 2,63 \\
\hline Kec. Kodeoha & 1,01 & 1,00 & 3,99 \\
\hline & & &
\end{tabular}




\begin{tabular}{cccc}
\hline Kec. Tiwu & 0,38 & 0,25 & 1,00 \\
\hline H & $\mathbf{2 , 6 0}$ & $\mathbf{2 , 0 7}$ & $\mathbf{7 , 9 0}$ \\
\hline Kec. Katoi & 1,00 & 0,85 & 2,40 \\
\hline Kec. Kodeoha & 1,18 & 1,00 & 4,50 \\
\hline Kec. Tiwu & 0,42 & 0,22 & 1,00 \\
\hline I & $\mathbf{2 , 5 9}$ & $\mathbf{2 , 2 5}$ & $\mathbf{6 , 7 5}$ \\
\hline Kec. Katoi & 1,00 & 1,00 & 1,72 \\
\hline Kec. Kodeoha & 1,00 & 1,00 & 4,03 \\
\hline Kec. Tiwu & 0,58 & 0,25 & 1,00 \\
\hline
\end{tabular}

Tabel 11. Hasil Perhitungan Matriks Aspek Penilaian Terhadap Lokasi

\begin{tabular}{cccccc}
\hline Kriteria & MEV & CI & RI & CR & Ket \\
\hline A & & & & & \\
\hline 1 & 3,12 & 0,06 & 0,58 & 0,11 & $\begin{array}{c}\text { CR }>0,10 \\
\text { tidak konsisten }\end{array}$ \\
\hline 2 & 3,04 & 0,02 & 0,58 & 0,04 & $\begin{array}{c}\text { CR } \leq 0,10 \\
\text { konsisten }\end{array}$ \\
\hline B & 3,06 & 0,03 & 0,58 & 0,05 & $\begin{array}{c}\text { CR } \leq 0,10 \\
\text { konsisten }\end{array}$ \\
\hline C & 3,07 & 0,04 & 0,58 & 0,06 & $\begin{array}{c}\text { CR } \leq 0,10 \\
\text { konsisten }\end{array}$ \\
\hline D & 3,04 & 0,02 & 0,58 & 0,04 & $\begin{array}{c}\text { CR } \leq 0,10 \\
\text { konsisten }\end{array}$ \\
\hline E & 3,04 & 0,02 & 0,58 & 0,03 & $\begin{array}{c}\text { CR } \leq 0,10 \\
\text { konsisten }\end{array}$ \\
\hline G & 3,01 & 0,01 & 0,58 & 0,01 & $\begin{array}{c}\text { CR } \leq 0,10 \\
\text { konsisten }\end{array}$ \\
\hline H & 3,03 & 0,01 & 0,58 & 0,03 & $\begin{array}{c}\text { CR } \leq 0,10 \\
\text { konsisten }\end{array}$ \\
\hline I & 3,09 & 0,04 & 0,58 & 0,07 & $\begin{array}{c}\text { CR } \leq 0,10 \\
\text { konsisten }\end{array}$ \\
\hline
\end{tabular}

\section{Pilihan Alternatif Lokasi}

Dari hasil pengolahan data diperoleh bobot kepentingan tiap-tiap alternatif yang disebut dengan bobot lokal. Untuk mencari alternatif yang terbaik maka harus dicari bobot global dengan cara mengalikan matriks bobot lokal disetiap kriteria dengan bobot lokal pada kriteria yang diuji. Proses sintesa menghasilkan prioritas alternatif sebagai berikut:

Tabel 12. Matriks Perhitungan Bobot

$$
\begin{array}{ll}
\text { Kecamatan Katoi } & =0,38 \\
\text { Kecamatan Kodeoha } & =0,47 \\
\text { Kecamatan Tiwu } & =0,15
\end{array}
$$

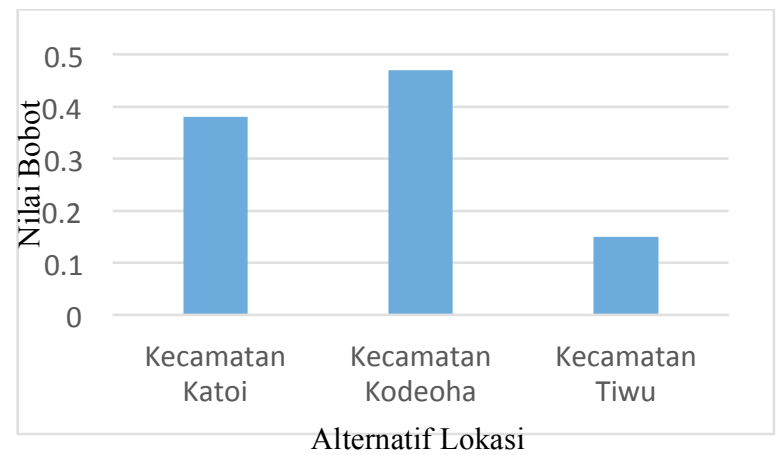

Gambar 6. Diagram Bobot Prioritas Terhadap Lokasi

Dari nilai bobot global hasil sintesis tersebut diatas tampak bahwa Kecamatan Kodeoha menjadi alternatif utama dalam penentuan lokasi bandar udara baru di Kabupaten Kolaka Utara. Hal ini disebabkan karena Kecamatan Kodeoha berada di tengah-tengah Kabupaten Kolaka Utara dan memiliki lahan yang berpotensi untuk dibangun sebuah bandara yakni area tambak dan persawahan yang sudah tidak produktif.

Kemudian alternatif yang kedua adalah Kecamatan Tiwu tepatnya di Desa Tahibua dimana Kecamatan ini berada dekat dari puast kegiatan Kecamatan Ngapa tetapi agak jauh dari Ibu Kota Kabupaten Kolaka Utara yaitu Kecamatan Lasusua.

Kemudian untuk alternatif yang ketiga adalah Kecamatan Katoi tepatnya di Desa Maruge. Hal ini disebabkan karena Kecamatan Katoi tidak memiliki lahan yang luas untuk pembangunan bandar udara baru.

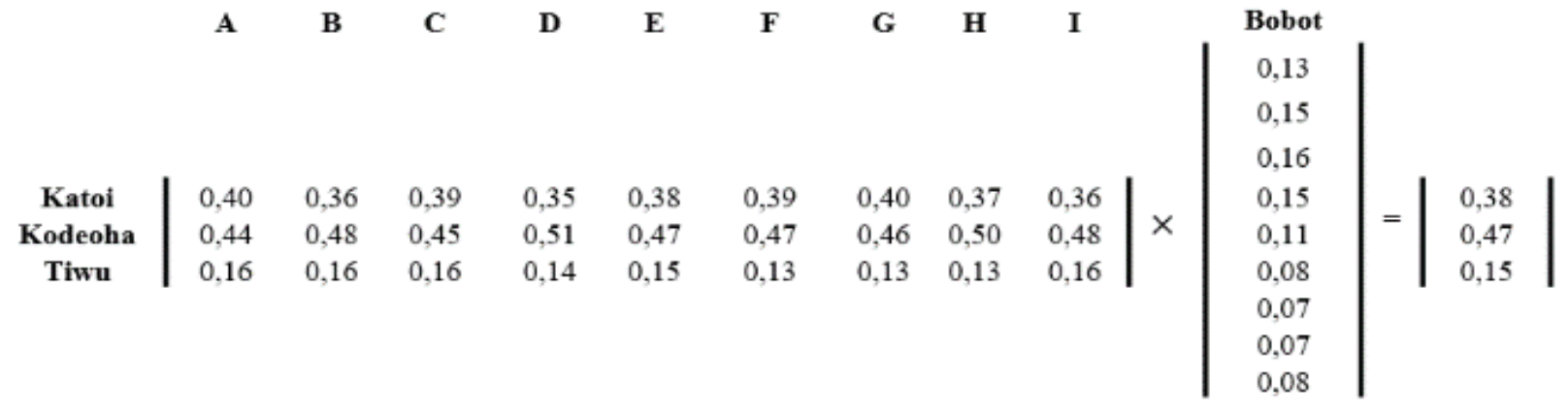




\section{KESIMPULAN}

Moda transportasi dari dan menuju Kolaka Utara dan sekitarnya terdapat dua moda yaitu moda transportasi darat dan moda transportasi laut. Pembangunan bandar udara di Kabupaten Kolaka Utara sangat dibutuhkan mengingat permintaan penumpang akan jasa angkutan udara cukup tinggi dalam 20 tahun kedepan. Selain itu, jarak menuju daerah-daerah sekitarnya cukup jauh dan memakan waktu yang cukup lama. Untuk menuju Kota Makassar menggunakan moda transportasi darat membutuhkan waktu 19 jam dengan jarak tempuh sejauh $701.1 \mathrm{~km}$ sedangkan dengan menggunakan moda transportasi multimoda membutuhkan waktu 11 jam dengan jarak tempuh $337.4 \mathrm{~km}$.

Lokasi alternatif yang sesuai berdasarkan hasil perhitungan AHP berada pada Kecamatan Kodeoha. Hal ini disebabkan karena Kecamatan Kodeoha berada di tengah-tengah Kabupaten Kolaka Utara dan memiliki lahan yang berpotensi untuk dibangun sebuah bandara yakni area tambak dan persawahan yang sudah tidak produktif.

\section{Daftar Pustaka}

Andriansyah. (2015). Manajemen Transportasi dalam Kajian dan Teori. Jakarta Pusat: Fakultas Ilmu Sosial dan Ilmu PolitikUniversitas Prof. Dr. Moestopo Beragama

Atmia, K. (2018). Peran ATC Supervisor, ATC Checker dan OJTI dalam Pelayanan Lalu Lintas Penerbangan di Bandara Mopah Merauke. AIRMAN: Jurnal Teknik dan Keselamatan Transportasi, 1(2), 24-29.

Badan Pusat Statistik Kabupaten Kolaka Utara (2019). Kabupaten Kolaka Utara dalam Angka Tahun 2019

Kementrian Negara Riset dan Teknologi Republik Indonesia. (2006). Penelitian, Pengembangan dan Penerapan Ilmu Pengetahuan dan Teknologi Indonesia 2005 - 2025. Jakarta: Bidang Teknologi dan Manajemen Transportasi.
Pemerintah Kabupaten Kolaka Utara Bidang Cipta Karya. Rencana Program Investasi Jangka Menengah (RPIJM) Tahun 20152019

Peraturan Daerah Kabupaten Kolaka Utara Nomor 6 Tahun 2012 Tentang Rencana Tata Ruang Wilayah Kabupaten Kolaka Utara Tahun 2012-2032

Peraturan Pemerintah Republik Indonesia Nomor 40 Tahun 2012 Tentang Pembangunan dan Pelestarian Lingkungan Hidup Bandar Udara

Peraturan Menteri Perhubungan Nomor: PM 69 Tahun 2013 Tentang Tatanan Kebandarudaraan Nasional

Pemerintah Kabupaten Kolaka Utara Dinas Perhubungan, Telekomunikasi dan Informatika. (2013). Pekerjaan Studi Kelayakan Pemilihan Lokasi dan Rencana Induk Bandar Udara Baru. Kolaka Utara: PT. Santika Consulindo

Rahman, Abdul. (2008). Penentuan Kriteria Yang Paling Berpengaruh Terhadap Prestasi Kerja Karyawan di Cv. Rimba Sentosa Sukoharjo. $\quad$ Skripsi: Universitas Muhammadiyah Surakarta. 